\title{
The Level of Awareness of Fast Food Operators on Food Safety and Hygiene Practices
}

\author{
Millicent Amoah*, Regina E. Adonu, Eric Paintsil \\ Department of Hospitality Management, Takoradi Technical University, Takoradi, Ghana \\ Email: *millyaby@gmail.com
}

How to cite this paper: Amoah, M., Adonu, R.E. and Paintsil, E. (2018) The Level of Awareness of Fast Food Operators on Food Safety and Hygiene Practices. Open Access Library Journal, 5: e4392. https://doi.org/10.4236/oalib.1104392

Received: February 1, 2018

Accepted: April 23, 2018

Published: April 26, 2018

Copyright $\odot 2018$ by authors and Open Access Library Inc.

This work is licensed under the Creative Commons Attribution International License (CC BY 4.0).

http://creativecommons.org/licenses/by/4.0/

\begin{abstract}
The growing fast food sector in the Ghanaian economy offers easy access to inexpensive food as well as new job opportunities for urban residents. While this development is positive in many ways, it also presents new public health challenges for the urban population. Maintaining safe food at the street level is a major concern to food control officers since outbreaks of most diarrheal diseases have been linked to street foods such as fast foods. This study concentrated on the level of awareness of fast food operators on food safety and hygiene practices in the Takoradi metropolis. Thirty-four fast food operators were selected through the stratified random sampling technique for extensive participant observations and to answer questionnaire. The study found out that although operators made up of the youth between the ages of 18 - 35 years demonstrated basic knowledge of food safety, the criteria used to define safe food by them did not emphasize basic hygiene practices such as hand washing, cleaning of utensils, washing of raw vegetables, and quality of ingredients. It also indicated that most $(91.2 \%)$ of the operators had no background in catering education. The study therefore recommends that food control departments in the country should put in place measures to ensure that every operator found in the fast food business has some kind of knowledge on the basics of the trade.
\end{abstract}

\section{Subject Areas}

Nutrition

\section{Keywords}

Fast Food, Hygiene, Food Safety

\section{Introduction}

During the last few decades, the street food sector has expanded rapidly in urban 
areas of low- and middle-income societies, both in terms of providing access to a diversity of inexpensive foods for low-income households and in offering job opportunities for many urban residents [1]. The street food sector also contributes to the economy of an urban and peri-urban agricultural sector [2]. Street food is a public health concern, since food hygiene can be difficult to practice at street level in settings where resources are scarce and surroundings are of low environmental and sanitary standards [3]. Diarrheal diseases due to contaminated and unhygienic food are among the leading causes of illnesses in most communities and are linked to street foods such as fast foods [4]. Increasing attention has therefore been given to the issue of hygiene in the food industry [5]. As a result, most street food vendors are challenged with the need to prepare and serve food under clean and hygienic conditions and with standardized procedures. Fast food service is a form of generating income for individuals and provides enormous benefit to the society at large. Fast food is delicious, inexpensive and convenient but also presents new public health challenge to consumers [6].

The hygienic aspects specified in the code of hygienic practices for food service establishments (FDB GLO5/FSE 01/1-2008) are a major concern for food control officers. Most fast food vendors are not knowledgeable when it comes to food safety and hygiene and what it entails. They mostly rely on their inadequate and sometimes wrong experience and practices in their operations, which the result is food borne illnesses. Personal hygienic practices such as the proper washing of the hands with germicidal soap under running water according to Peach [7] as well as keeping the finger nails short and clean [8], covering food when cooking, serving food at the correct temperature and using the right method for cooking and serving food [9] are some of the key ways of maintaining safe food at the street level. It is usual to find cold and hot holding equipment for every fast food item in fast food outlets such as KFC, McDonalds and Burger kings among others in the United Kingdom and the United States of America [6]. The methods used to store leftover food can either aid in the multiplication of bacteria or the prevention of their growth. Portioning food into smaller quantities and storing in the refrigerator not only prevents bacteria growth but also preserves the quality of the food [5].

Fast food operators in Ghana are mostly not educated when it comes to catering [10]. Most people enter this trade because there are no rules that say that an individual without any catering educational background cannot become a fast food operator. However, uncontrolled street fast food vending could result in serious environmental hygiene problems and possible deterioration in law and order in the event of unscrupulous practices by the operators. This research work focused on the level of awareness of fast food operators of food safety and hygiene practices in the Takoradi metropolis.

\section{Research Methodology}

The descriptive survey design was used for the study. The population for the study was operators of street fast foods. A sample of thirty-four (34) street fast 
food operators were selected from different suburbs within Takoradi using the stratified random sampling. This was done by writing down the locations where fast food operation was prominent within Takoradi metropolis, and a number of operators were randomly picked from each location. The research was carried out from January 2011 to June 2013.

Questionnaire and observations were used to collect the data. The information sought from respondents dwelt mostly on their knowledge on hygienic standards of food preparation and service and how they could be implemented. Observations were also made on the conditions under which foods were prepared and sold to customers. The data collected for the study was in different forms. The questionnaire was administered to the literate respondents whereby they were allowed to bring out their views freely. The illiterate respondents were also made to respond to the questionnaire. With this, the questions from the questionnaire were read and interpreted by the researcher for them to react after which the researcher collated all the responses given. Observations were also made to get data that respondents were not willing to provide. The data collected was analyzed with the use of SPSS and presented in frequency distribution tables and charts. Each question was analyzed and generalizations made after each analysis. Responses with highest percentages were considered to be the general opinion with regards to that question.

\section{Results and Discussions}

\subsection{Respondents Demographics}

The total number of respondents used for the study was thirty-four (34). Out of these, $91.2 \%$ (31) were males with the remaining $8.8 \%$ (3) being females. This means that majority of the respondents were males. The most dominant age group was between the ages 26 - 30 years representing 55.9\% (19) of the respondents used for the study followed by 31 - 35 years representing $23.5 \%$ (8). The lowest age representation was those below 25 years representing 20.6\% (7). Majority (79.4\%) of the respondents had been in operation of the fast food business for 1 - 5 years. $14.7 \%$ (5) had been operating for less than one year with a few (5.9\%) operating for between 6 - 10 years. Responses on respondents' educational level revealed that $91.2 \%$ (31) had non-formal education with $5.9 \%$ (2) and 2.9\% (1) having Advance certificate and Higher National Diploma respectively. 91.2\% (31) said they had no background in catering education whilst 8.8\% (3) admitted they had some catering educational background.

\subsection{Fast Food Operators Understanding on Kitchen Hygiene}

Figure 1 shows the responses of fast food operators regarding their understanding of kitchen hygiene. It indicates that $85.3 \%$ (29) of them understood kitchen hygiene to be the cleaning of the kitchen and its equipment while $14.7 \%$ (5) of them understood it to be sweeping the kitchen. These responses indicate that most of the sampled population had an idea on what kitchen hygiene is and were 


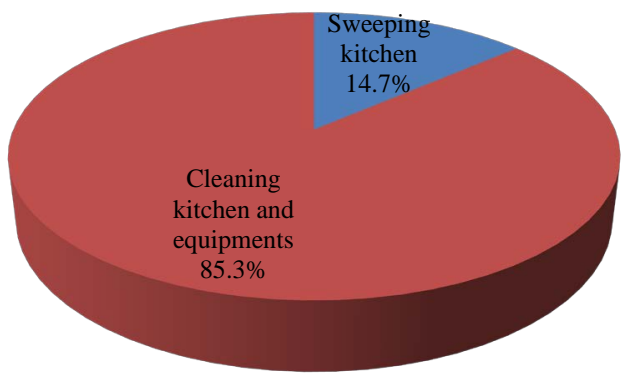

Figure 1. Food operators' understanding of kitchen hygiene. Source: author's field data 2013.

aware of what should be done to ensure that a kitchen is kept clean and safe for food preparation and service.

As to the frequency at which cleaning was done at the food service area and working surfaces/tops by operators, $85.3 \%$ (29) said they cleaned their service area after a day's work; $8.8 \%$ (3) did the cleaning daily thus every morning before the commencement of work whilst a few of them (5.9\%) cleaned weekly. Again, $61.7 \%$ (21) of them cleaned their working surfaces daily, whilst 38.3\% (13) does it weekly. These responses explain Ridgewell's, [5] assertion that increasing attention has been given to the issue of hygiene in the food industry. As such most food operators are being challenged with the need to prepare and serve food under clean and hygienic conditions. Observations by the researcher however revealed that, about $74 \%$ (25) of the operators waited till the following morning before they carried out the cleaning of the food production area which did not even have trap doors. This practice however has serious microbiological implications such as the multiplication of food poisoning bacteria. Leaving the food production area and utensils dirty till the following day provides the right medium for the multiplication of both spore and non-spore forming bacteria such as E. Coli and Staphylococcus Aeureus.

\subsection{Operators Understanding of Personal Hygiene}

Though 33 of the respondents (97.1\%) were aware of the term personal hygiene, the responses given by the operators on their personal hygienic practices proved otherwise. On the issue of hand washing, all the operators responded that they did wash their hands, but the problem had to do with the frequency and the methods used. 58.8\% (20) washed their hands as often as possible whilst the remaining $41.2 \%$ (14) said they did so before and after cooking. As to the methods used, responses from the operators as demonstrated in Table 1 shows that $70.6 \%$ (24) used only water (cold) with 4 (11.8\%) using hot water and soap. $14.7 \%$ (5) of them cleaned their hands by wiping with napkin with the remaining $2.9 \%$ (1) not giving any response at all.

This finding is a health concern since the improper washing of hands can cause food contamination leading to food infection or poisoning. Peach [7], also explains that using ordinary water without germicidal soap to wash the hands does not remove most of the bacteria and the dirt found on it. He went on to say 
Table 1. Ways of cleaning hands after handling raw products.

\begin{tabular}{ccc}
\hline Method & Frequency & Percentage (\%) \\
\hline Wipe with Napkin & 5 & $14.7 \%$ \\
Wash with Cold Water & 24 & $70.6 \%$ \\
Wash with Hot Water and Soap & 4 & $11.8 \%$ \\
No Response & 1 & $2.9 \%$ \\
Total & 34 & 100.0
\end{tabular}

Source: author's field data 2013.

that the hands should be washed under running water after handling any raw material or waste whiles cooking and this should be done with a germicidal soap. It is therefore important to note that keeping the finger nails short as well as washing the hands with soap and water also ensures that the finger nail is clean. This is in line with what Ceserani [8] explained that the hands including the finger nail should be kept clean by food handlers. The nails should also be short. Observations however by the researcher revealed that, $82.4 \%$ (28) of the operators had short nails however $91.2 \%$ (31) out of the number had their nails very dirty. This practice however, can have an adverse effect on the safety of food sold to consumers of fast foods since these dirty nails can harbor a lot of the bacteria that causes food contamination.

\subsection{Food Safety and Cross Contamination}

This study proved that operators did have some measures they put in place to ensure the safety of cooked foods. Figure 2 shows that, covering food when cooking (73.5\%), cooking and serving food at the right temperature $(26.5 \%)$ and using the correct method for cooking and serving were some of the important measures used by operators to ensure food safety in their operations. This as explained by Trickett [9] are some of the surest way to preventing food contamination and poisoning. One rather important positive observation by the researcher was that most of the operators used for the study covered their food during and after cooking. The problem had to do with the temperature at which these foods were stored and served to customers. Keeping and serving foods at the right temperature and time is something that is of importance to fast food operators in many developed countries. It is usual to find cold and hot holding equipment for every fast food item in fast food outlets such as KFC, McDonalds and Burger kings among others in the United Kingdom and the United States of America [6]. But this is not the case in Ghana. Most (31) of the operators used for the study did not have adequate up to date equipment for keeping their food at the right temperature. It was common to find salad being kept in a bowl and under normal room temperature. These practices rather lead to the serving of hot foods cold and cold foods hot. 


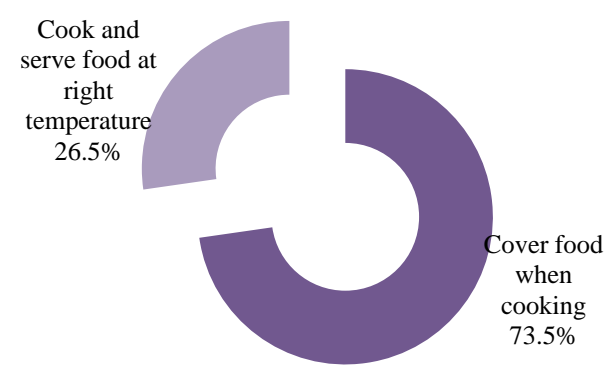

Figure 2. Measures for food safety.

The use of a teaspoon for tasting when cooking is a hygienic way of tasting food. However, the study revealed that 24 of the operators (70.6\%) were not fond of this practice but would rather use their hand, a ladle or anything handy. These other means are not hygienic or safe and can cause cross contamination leading to food poisoning. Time and temperature abuse is another factor that leads to food poisoning. From the study most operators were seen to be ignorant of this fact. They (44.1\%) reheated and (55.9\%) added leftover food to the next day's food without considering the fact that the food (salad, chicken, fish, gravy) had been left at room temperature for some time and as such had become poisonous. As to how this leftover food was treated before storage the study revealed that $75.5 \%$ (26) portioned the food into smaller quantities before storing in a refrigerator. A very alarming revelation from the study was that some (73.5\%) of the operators stored leftover foods by covering and leaving in the kitchen. This practice according to Ridgewell [5] allows for the multiplication of food spoilage and poisoning bacteria in cooked foods. The main problem is that unsuspecting consumers go in and buy these foods.

\section{Conclusions}

After critically analyzing the various data collected for the study, it can be concluded that majority (91.2\%) of fast food operators in the Takoradi metropolis had no background in catering education but were in operation because there is no law in Ghana stating that an individual without a catering background cannot operate a fast food joint.

Concerning the hygiene practices to be put in place to ensure food safety in their operations, it can be concluded that operators were aware of these practices but did not adhere to most of the major activities (food safety and cross contamination, food safety principles, food hygiene, kitchen hygiene and personal hygiene).

\section{Recommendations}

Food control departments in the country should put in place measures to ensure that every operator found in the fast food business has some kind of knowledge on the basics of the trade.

Operators and food control officers should note that, formal food safety edu- 
cation is very important to secure safer street fast food. Education on food safety and hygiene should be provided for operators so as to improve their knowledge on the causes and prevention of food poisoning.

Food safety experts should also find it crucial to understand vendors' social and normative perceptions of food safety. Neglected aspects of neatness, such as good hand hygiene and cleanliness of kitchen facilities, especially, should be emphasized.

\section{References}

[1] Maxwell, D., Levin, C., Amar-Klemesu, M., Ruel, M., Morris, S. and Ahiadekeet, C. (2000) Urban Livelihood and Food and Nutrition Security in Greater Accra. International Food Policy Research Institute Report, No. 112, 11-18.

[2] Amoah, P., Drechsel, P., Abaidoo, R.C. and Ntow, W.J. (2006) Pesticide and Pathogenic Contamination of Vegetables in Ghana's Urban Markets. Arch Environment Contaminant, 50, 21-25.

[3] Mensah, P., Armar-Klemesu, M., Hammond, A.S. and Nyarko, R. (2001) Bacteria Contaminants of Lettuce, Tomatoes Beef and Goat from the Accra Metropolis. Ghana Medical Journal, 33, 162-167.

[4] World Health Organization (2009) Increasing Impact through Collaboration: Food Borne Disease Stakeholders Meeting. http://www.who.int/foodsafety/foodborne_disease/FERG_Stakeholder_2008.pdf?ua $=1$

[5] Ridgewell, J. (1996) Examining Food and Nutrition. Heineman Educational Publishers, Oxford.

[6] Ninemeir, J.D. (2005) Management of Food and Beverage Operations. 4th Edition, American Hotel and Lodging Education, Michigan.

[7] Peach, L. and Thompson, D. (1987) Health Service Catering: Hygiene. 3rd Edition, Her Majesty's Stationery Office, London.

[8] Ceserani, V., Kinton, R. and Foskett, D. (2000) Practical Cookery. 9th Edition, Hodder and Stoughton Educational Headline PLC, London.

[9] Trickett, J. (1991) The Prevention of Food Poisoning. 2nd Edition, Stanley Thornes Publishers Limited, Cheltenham.

[10] Quarmine, E. (2011) Safety of Fast Foods in Ghana: Ghana News Agency Feature (Accra). http://www.ghanaweb.com 